\title{
Assessment of DBA-L Pressure Vessel Design Method by a Cylindrical Vessel with Hemispherical Ends
}

\author{
Xincheng Ren ${ }^{1}$, Hongjun $\mathrm{Li}^{1}$, Xun Huang ${ }^{2}$ \\ ${ }^{1}$ Zhejiang Sci-Tech University, Faculty of Mechanical Engineering and Automation, 310018, Hangzhou, China \\ ${ }^{2}$ Southeast University, Nanjing 210096, China
}

\begin{abstract}
Stress categorization is an essential procedure in Design by Analysis (DBA) pressure vessel design methods based on elastic analysis in ASME and EN code. It was difficult to implement especially around structural discontinuities. A new elastic analysis, DBA-L, was proposed recently to avoid stress categorization. A model of the cylindrical pressure vessel with spherical end is used to check the validity of this method by comparing with other design methods based on stress categorization procedures and elasticplastic stress analysis from ASME and EN code. The results indicate that the DBA-L is an economic and explicit method, and can be used an alternative method to stress categorization.
\end{abstract}

\section{Introduction}

To protect against Gross Plastic Deformation (GPD) of the pressure vessel, both Design by Formula (DBF) and Design by Analysis (DBA) methods can be used to carry out design procedure. DBF considers a membrane stress state condition to determine the minimum wall thickness and large safety factors are used at areas of geometric discontinuities leading to the thicker wall [1]. DBA performs detailed stress analysis for the vessel including the complex geometric features. It is now the most commonly used techniques for pressure vessel design and was introduced in many national standards, codes and guidelines such as ASME VIII-2[2], EN13445[3] and JB4732-95[4].

There are two types of DBA design methods which are based on elastic analysis and inelastic analysis, respectively. In inelastic DBA, gross plastic deformation is prevented by limiting the load applied to the vessel, restricting it to a fraction of the notional ductile collapse load of the vessel. The elastic analysis design assumes elastic mechanics and shell theory [5], and the procedure includes a check against gross plastic deformation (GPD). First, the design loads are applied and the membrane and bending stress distributions are computed by stress linearization method. The designer needs to classify the derived membrane and bending stress distributions into primary or secondary stress according to pressure vessel design codes. Different stresses are then limited to certain value, the general primary membrane stress should be less than Sm (two thirds of yield stress), local primary membrane stress less than $1.5 \mathrm{Sm}$, and primary membrane plus bending stresses less than $1.5 \mathrm{Sm}$. Therefore, the stress categorization procedure for primary stress may therefore be considered to be a form of lower bound limit load analysis.
The approach of stress categorization was proposed by Kroenke [6] who established the method to derive the required stresses from $\mathrm{FE}$ results. However stress categorization encountered many problems in practical use; especially distinguish primary and secondary stresses from the total stress for geometry discontinuous regions [7-10]. The current authors [11] proposed a new design method, DBA-L, based on elastic analysis and the lower bound limit load to avoid the problematic stress categorization. This paper assessed the effectiveness of DBA-L by comparing with other design methods.

\section{DBA-L design method}

As in the stress categorization method, a Stress Classification Line, SCL, was defined through the thickness of the structure, considering a doubly curved elastic body representing part of a complex pressure vessel as shown in Figure 1. Unlike other elastic design methods where the stress distribution along the SCL was linearized, a stepped stress distribution was assumed in DBA-L, as illustrated in Figure 2. The stepped through thickness distribution was the general limit state stress distribution in a beam under combined membrane and bending load. This form of stress distribution can be defined in terms of parameters $\sigma_{a}$ and $d$, which can be derived by the force and moment equilibrium conditions in SCL as shown in Equations (1) and (2) [11]. 


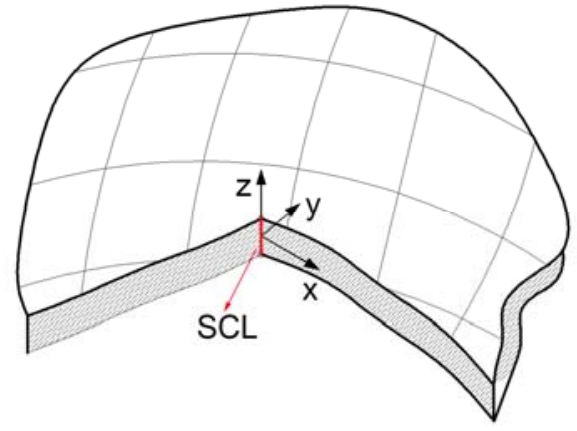

Fig. 1. Stress Classification Line.

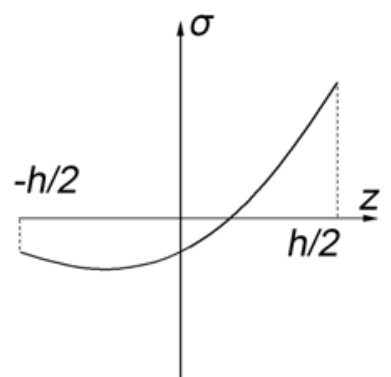

(a)

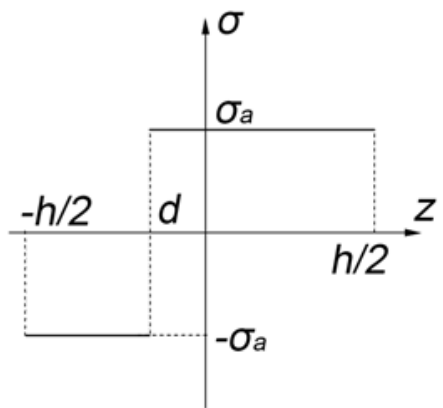

(b)

Fig. 2. The stress distribution through the thickness of vessels: (a) The true stress distribution; (b) The assumed stress distribution [11].

Fig. 3. The schematic of determining single valued parameter $\sigma_{\mathrm{a}}$ and $\mathrm{d}$ [11].

$$
\begin{gathered}
\frac{N}{b}=\int_{-\frac{h}{2}}^{\frac{h}{2}} \sigma d z=-\int_{-\frac{h}{2}}^{d} \sigma_{a} d z+\int_{d}^{\frac{h}{2}} \sigma_{a} d z=-2 \sigma_{a} d \\
\frac{M}{b}=\int_{-\frac{h}{2}}^{\frac{h}{2}} \sigma d z=-\int_{-\frac{h}{2}}^{d} \sigma_{a} z d z+\int_{d}^{\frac{h}{2}} \sigma_{a} z d z=\sigma_{a}\left(\frac{h^{2}}{4}-d^{2}\right)
\end{gathered}
$$

Substituting $\sigma_{\mathrm{a}}$ from (1) into (2) and rearranging gives:

$$
\frac{N d^{2}}{2}-M d-\frac{N h^{2}}{8}=0
$$

The roots of the quadratic equation (3) are:

$$
d=\frac{M \pm \sqrt{M^{2}+N^{2} h^{2} / 4}}{N}
$$

There are two $d$ values calculated in the above equitions. The unique value of $d$ can be determined by considering the direction of moment and total force acting on LAL from true stress distribution, as shown in Fig. 3.

Von Mises stresses along all SCLs are calculated respectively based on the $\sigma_{a}$ of six stress components. The minimum value of von Mises stress on each SCL for the applied load set $\mathrm{P}, \sigma_{e}^{p}$, is identified. The ratio of $\sigma_{e}^{p}$ to the yield stress is a limit load multiplier $\lambda$, and then the proportional loading limit load $\mathrm{P}_{\mathrm{LL}}$ for each SCL is $\mathrm{P} / \lambda$. The minimum value $\mathrm{P}_{L L}$ among all the SCLs is the limit load $P_{L}$ of the vessel and the design load $P_{d}$ is two thirds of $\mathrm{P}_{\mathrm{L}}$.

\section{Model}

The geometry and FE model of the cylindrical vessel with hemispherical end was shown in Figure 4. Due to the axisymmetry, only a quarter of the cross-section was modeled in ANSYS with PLANE183 element. The bottom horizontal edge was constrained with a symmetric boundary condition and pressure was applied on the internal surface of the vessel. The model material properties were given in Table 1.

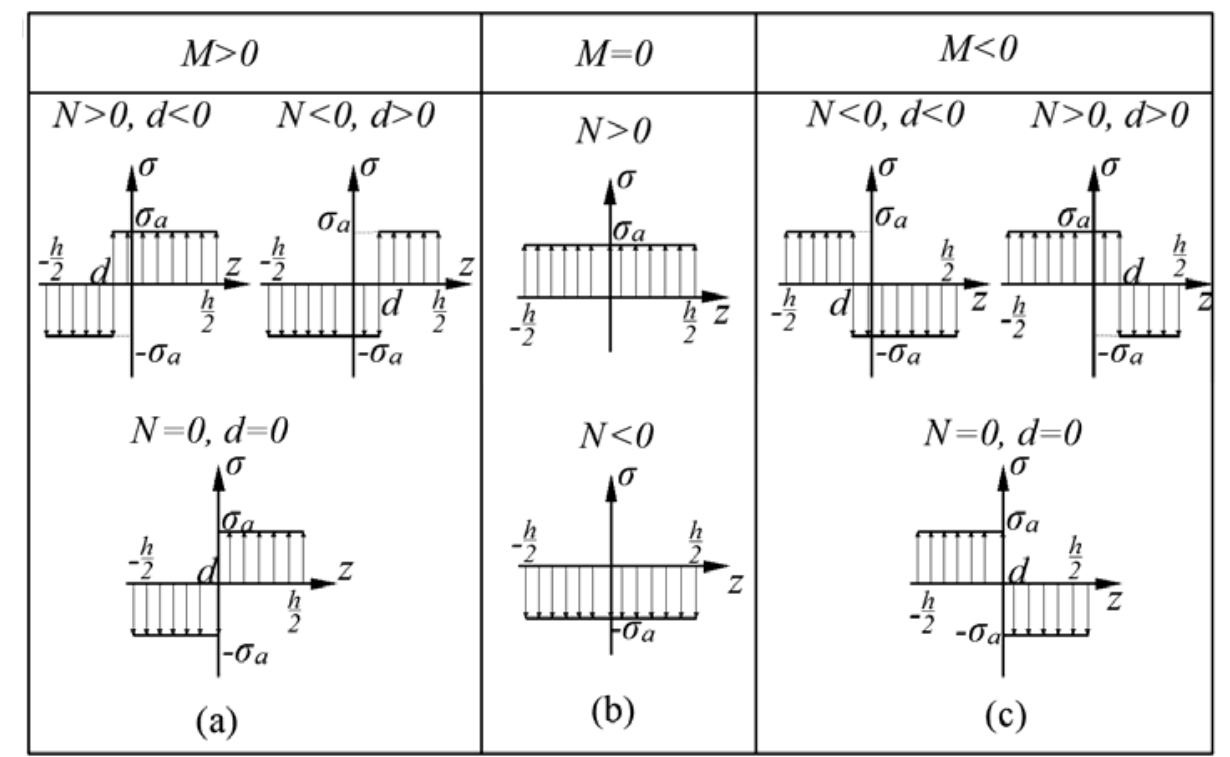




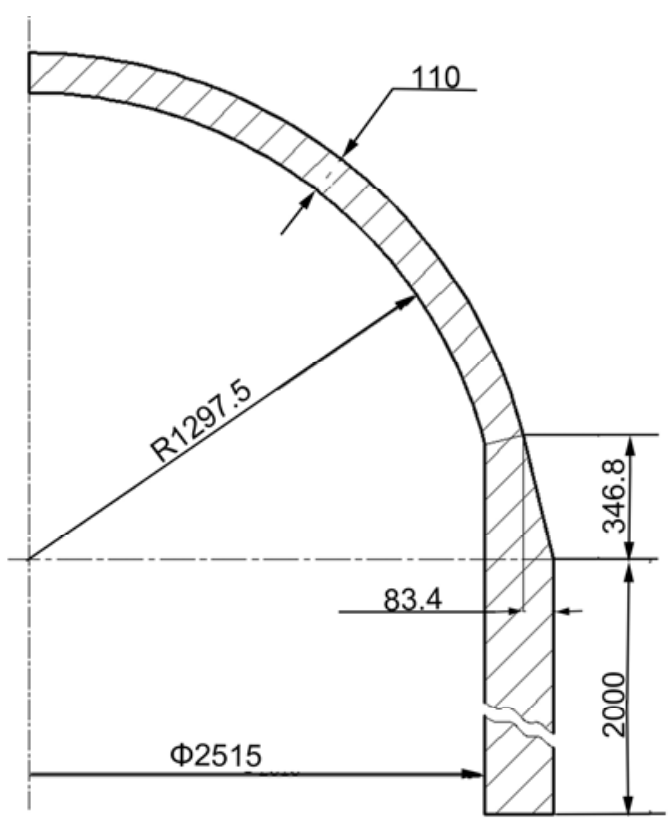

(a)

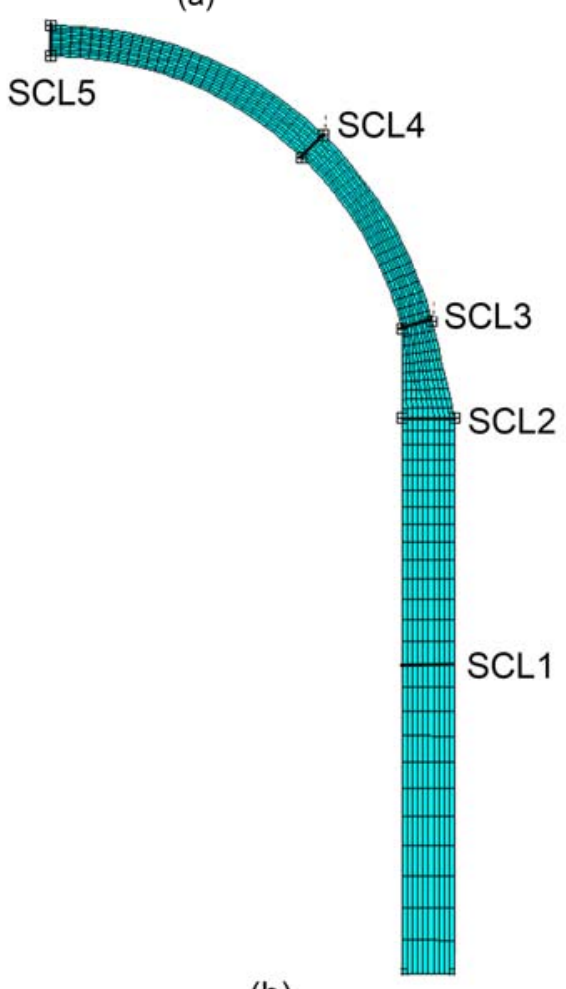

(b)

Fig. 4. The cylindrical vessel with hemispherical end (a) geometry (b) FE model.

Table 1. Material properties used in the model.

\begin{tabular}{|c|c|c|c|c|}
\hline $\begin{array}{c}\text { Poison's } \\
\text { ratio }\end{array}$ & $\begin{array}{c}\text { Yong's } \\
\text { modulus } \\
\text { (GPa) }\end{array}$ & $\begin{array}{c}\text { Yield } \\
\text { Stress } \\
\boldsymbol{\sigma}_{\text {yield-true }} \\
\text { (MPa) }\end{array}$ & $\begin{array}{c}\text { Yield } \\
\text { Stress } \\
\boldsymbol{\sigma}_{\text {yield-Tresca }} \\
\text { (MPa) }\end{array}$ & $\begin{array}{c}\text { Tensile } \\
\text { strength } \\
\text { (MPa) }\end{array}$ \\
\hline 0.3 & 212 & 255 & 220 & 415 \\
\hline
\end{tabular}

The design procedure was carried out according to Elastic analysis and Elastic-Plastic analysis methods in ASME design code, the Design by Analysis method based on stress categorization in EN13445 method, and the DBA-L method. However there were only two types of computation in the finite element analysis, elastic analysis and elastic-plastic analysis. For EN13445 elastic analysis, two yield criteria were adopted: Tresca and von Mises, while in ASME and DBA-L design procedure, only von Mises was used. Limit load analysis assumes elastic-perfect plastic material model and small deformation theory, but large deformation effect can also be included in elastic-plastic analysis. For pressure vessel design procedure based on elastic analysis, Stress Categorization Line (SCL) must be defined. In this model, five stress assessment regions were considered, SCL1SCL5 as illustrated in Figure 4. The six stress components were calculated and linearized along the SCLs.

\section{Equations and mathematics}

The elastic analysis results for each SCL and stress category were tabulated in Table 2 . There were two stress categories, Membrane stress (M) and Membrane plus Bending stress $(\mathrm{M}+\mathrm{B})$. The allowable stress equal to $2 / 3$ of the yield stress was used to compute the allowable load for each SCL. The minimum allowable load among all the SCL was taken as the allowable load for the vessel.

Table 2. Elastic analysis results.

\begin{tabular}{|c|c|c|c|c|c|c|c|c|c|}
\hline \multirow{3}{*}{$\begin{array}{l}\mathrm{S} \\
\mathrm{C} \\
\mathrm{L}\end{array}$} & \multirow{3}{*}{$\begin{array}{c}\text { Stres } \\
\text { s } \\
\text { cate } \\
\text { gory }\end{array}$} & \multicolumn{4}{|c|}{$\begin{array}{c}\text { Equivalent stress } \\
\text { (MPa) }\end{array}$} & \multicolumn{4}{|c|}{ Allowable load (MPa) } \\
\hline & & AS & \multicolumn{2}{|c|}{ EN } & \multirow{2}{*}{$\begin{array}{c}\text { DB } \\
\text { A- } \\
\text { L } \\
\text { Mi } \\
\text { ses }\end{array}$} & AS & \multicolumn{2}{|c|}{ EN } & \multirow{2}{*}{$\begin{array}{c}\text { DB } \\
\text { A- } \\
\text { L } \\
\text { Mi } \\
\text { ses }\end{array}$} \\
\hline & & $\begin{array}{c}\text { Mis } \\
\text { es }\end{array}$ & $\begin{array}{l}\text { Tre } \\
\text { sca }\end{array}$ & $\begin{array}{l}\mathrm{Mi} \\
\text { ses }\end{array}$ & & $\begin{array}{c}\text { Mis } \\
\text { es }\end{array}$ & $\begin{array}{l}\text { Tre } \\
\text { sca }\end{array}$ & $\begin{array}{l}\text { Mi } \\
\text { ses }\end{array}$ & \\
\hline \multirow{2}{*}{1} & $\mathrm{M}$ & $\begin{array}{l}16 . \\
60\end{array}$ & $\begin{array}{l}18 . \\
72\end{array}$ & $\begin{array}{l}16 . \\
60\end{array}$ & \multirow{2}{*}{$\begin{array}{l}16 . \\
23\end{array}$} & $\begin{array}{l}10 . \\
24\end{array}$ & $\begin{array}{c}7.8 \\
7\end{array}$ & $\begin{array}{l}10 . \\
24\end{array}$ & \multirow{2}{*}{$\begin{array}{l}10 . \\
47\end{array}$} \\
\hline & $\begin{array}{c}\mathrm{M}+ \\
\mathrm{B}\end{array}$ & $\begin{array}{l}17 . \\
11\end{array}$ & $\begin{array}{l}18 . \\
73\end{array}$ & $\begin{array}{l}17 . \\
42\end{array}$ & & $\begin{array}{l}14 . \\
91\end{array}$ & $\begin{array}{l}11 . \\
79\end{array}$ & $\begin{array}{l}14 . \\
64\end{array}$ & \\
\hline \multirow{2}{*}{2} & $\mathrm{M}$ & $\begin{array}{l}11 . \\
00\end{array}$ & $\begin{array}{l}12 . \\
70\end{array}$ & $\begin{array}{l}11 . \\
00\end{array}$ & \multirow{2}{*}{$\begin{array}{c}9.8 \\
4\end{array}$} & $\begin{array}{l}23 . \\
17\end{array}$ & $\begin{array}{l}17 . \\
38\end{array}$ & $\begin{array}{l}23 . \\
17\end{array}$ & \multirow{2}{*}{$\begin{array}{l}17 . \\
27\end{array}$} \\
\hline & $\begin{array}{c}\mathrm{M}+ \\
\mathrm{B}\end{array}$ & $\begin{array}{l}11 . \\
07\end{array}$ & $\begin{array}{l}13 . \\
00\end{array}$ & $\begin{array}{l}11 . \\
33\end{array}$ & & $\begin{array}{l}23 . \\
03\end{array}$ & $\begin{array}{l}16 . \\
99\end{array}$ & $\begin{array}{l}22 . \\
50\end{array}$ & \\
\hline \multirow[b]{2}{*}{3} & $\mathrm{M}$ & $\begin{array}{c}9.4 \\
5\end{array}$ & $\begin{array}{c}9.5 \\
4\end{array}$ & $\begin{array}{c}9.4 \\
5\end{array}$ & \multirow{2}{*}{$\begin{array}{l}10 . \\
59\end{array}$} & $\begin{array}{c}26 . \\
98\end{array}$ & $\begin{array}{r}23 . \\
14\end{array}$ & $\begin{array}{l}26 . \\
98\end{array}$ & \multirow{2}{*}{$\begin{array}{l}16 . \\
06\end{array}$} \\
\hline & $\begin{array}{c}\mathrm{M}+ \\
\mathrm{B}\end{array}$ & $\begin{array}{l}12 . \\
85\end{array}$ & $\begin{array}{l}14 . \\
47\end{array}$ & $\begin{array}{l}13 . \\
13\end{array}$ & & $\begin{array}{l}19 . \\
85\end{array}$ & $\begin{array}{l}15 . \\
26\end{array}$ & $\begin{array}{l}19 . \\
42\end{array}$ & \\
\hline \multirow{2}{*}{4} & $\mathrm{M}$ & $\begin{array}{c}9.0 \\
1\end{array}$ & $\begin{array}{l}10 . \\
38\end{array}$ & $\begin{array}{c}9.0 \\
1\end{array}$ & \multirow{2}{*}{$\begin{array}{c}9.0 \\
1\end{array}$} & $\begin{array}{l}18 . \\
87\end{array}$ & $\begin{array}{l}14 . \\
19\end{array}$ & $\begin{array}{l}18 . \\
87\end{array}$ & \multirow{2}{*}{$\begin{array}{l}18 . \\
87\end{array}$} \\
\hline & $\begin{array}{c}\mathrm{M}+ \\
\mathrm{B}\end{array}$ & $\begin{array}{c}9.0 \\
3\end{array}$ & $\begin{array}{l}12 . \\
75\end{array}$ & $\begin{array}{l}11 . \\
05\end{array}$ & & $\begin{array}{l}28 . \\
24\end{array}$ & $\begin{array}{l}17 . \\
31\end{array}$ & $\begin{array}{l}23 . \\
07\end{array}$ & \\
\hline \multirow[b]{2}{*}{5} & $\mathrm{M}$ & $\begin{array}{l}11 . \\
09\end{array}$ & $\begin{array}{l}12 . \\
53\end{array}$ & $\begin{array}{l}11 . \\
09\end{array}$ & \multirow{2}{*}{$\begin{array}{l}10 . \\
25\end{array}$} & $\begin{array}{l}15 . \\
33\end{array}$ & $\begin{array}{l}11 . \\
75\end{array}$ & $\begin{array}{l}15 . \\
33\end{array}$ & \multirow{2}{*}{$\begin{array}{l}16 . \\
59\end{array}$} \\
\hline & $\begin{array}{c}\mathrm{M}+ \\
\mathrm{B}\end{array}$ & $\begin{array}{l}11 . \\
48\end{array}$ & $\begin{array}{l}13 . \\
23\end{array}$ & $\begin{array}{c}11 . \\
68\end{array}$ & & $\begin{array}{c}22 . \\
21\end{array}$ & $\begin{array}{c}16 . \\
69\end{array}$ & $\begin{array}{l}21 . \\
84\end{array}$ & \\
\hline
\end{tabular}

It can be seen in Table 2 that the equivalent stresses in SCL1 was the highest and the corresponding allowable load was lowest for all the design methods, indicating that the cylindrical part was the weakest and explained why its thickness was greater than that of the spherical end. the equivalent stress by DBA-L was lower than the membrane plus bending stresses of all SCLs by ASME or 
EN elastic design procedure, but the allowable load for each SCL was in between values computed by ASME and EN methods.

The EN method gave the highest value for each SCL. In SCL4, the equivalent stress by $\mathrm{EN}$ method based on Mises was 22\% lower than ASME method, resulting in $22 \%$ difference in allowable load. This is due to the difference in stress linearization method by two codes. EN13445 linearizes all the six stress components to calculate membrane and membrane plus bending stress, but ASME only considers hoop stress, meridional stress and in-plane shear stress to calculate membrane plus bending stress since the radial stress and out-of-plane shear stresses don't give rise to bending moment. The membrane and bending stress of the six stress components for SCL4 was given in Table 3. The out-ofplane shear stress $\tau_{y z}$ was significant comparing with other stress components, and have a big influence on the calculated equivalent stress.

Table 3. The membrane and bending stress of the six stress components for SCL4.

\begin{tabular}{|c|c|c|c|c|c|c|}
\hline $\begin{array}{c}\text { Stress } \\
\text { category }\end{array}$ & $\sigma_{x}$ & $\sigma_{y}$ & $\sigma_{z}$ & $\tau_{x y}$ & $\tau_{y z}$ & $\tau_{z x}$ \\
\hline $\mathrm{M}$ & 4.63 & 5.34 & 4.82 & 0.00 & -5.19 & 0.00 \\
\hline $\mathrm{B}$ & 0.65 & 0.51 & 0.73 & 0.00 & -1.19 & 0.00 \\
\hline
\end{tabular}

The allowable load (design pressure) was defined as two thirds of the limit load and plastic collapse load in limit load analysis and elastic-plastic analysis, respectively. The design pressures by all the design methods were summarized in Table 4. EN (Tresca) method produced the most conservative design pressure. ASME and EN (Mises) method had the same results, as in SCL1, the allowable load was determined by equivalent membrane stress which was the same for both methods. DBA-L design pressure was the highest among all the elastic analysis methods, but lower than that of the elastic-plastic analysis with large deformation. Comparing the design loads by small deformation and large deformation analysis, the vessel exhibited geometric strengthening effect.

Table 4. Design pressures by elastic analysis and elastic-plastic analysis.

\begin{tabular}{|c|c|c|c|c|c|}
\hline \multicolumn{9}{|c|}{ Vessel design pressure (MPa) } \\
\hline \multicolumn{3}{|c|}{ Elastic analysis design } & \multicolumn{2}{c|}{$\begin{array}{c}\text { Elastic-plastic analysis } \\
\text { design }\end{array}$} \\
\hline \multirow{2}{*}{$\begin{array}{c}\text { ASM } \\
\text { E }\end{array}$} & \multicolumn{2}{|c|}{ EN } & $\begin{array}{c}\text { Small } \\
\text { DBA } \\
\text {-L }\end{array}$ & $\begin{array}{c}\text { deformation } \\
\text { theory } \\
\text { (Limit load } \\
\text { analysis) }\end{array}$ & $\begin{array}{c}\text { Large } \\
\text { deformation } \\
\text { theory }\end{array}$ \\
\cline { 2 - 3 } & Trseca & Mises & 10.37 & 11.88 \\
\hline 10.24 & 7.87 & 10.24 & 10.47 & 10.37 & \\
\hline
\end{tabular}

\section{Conclusions}

The effectiveness of the DBA-L pressure vessel design method based on elastic analysis and lower bound limit load theory was assessed by comparing with other popular design method through an example of the cylindrical vessel with hemispherical ends. DBA-L method avoided the troublesome stress categorization process and simplified the Design by Analysis pressure vessel design procedure. From the calculated design results, it was found that DBA-L along with other methods identified the weakest part of the vessel in the same area. The design pressure by DBA-L was the highest among all the elastic analysis methods, and the least material could be used to construct the vessel, but the DBA-L design pressure was $14 \%$ lower than that of the elastic-plastic analysis design method with large deformation theory, indicating that the DBA-L was an economic and conservative design method.

\section{Acknowledgement}

This research was supported by Natural Science Foundation of China under Grant No. 51605444 and Zhejiang Provincial Top Key Discipline of Mechanical Engineering foundation, China under Grant No. ZSTUME01B12.

\section{References}

1. A. Diamantoudis, T. Kermanidis, INT J PRES VES PIP 82.1, 43 (2005)

2. ASME boiler \& pressure vessel Code, VIII division 2, (ASME, New York, 2015)

3. BS EN13445-3, Unfired Pressure Vessels, 2009

4. JB4732-95, Steel pressure vessels-Design by Analysis, (China Machine Press, Beijing, 1995)

5. J. Reddy, Theory and Analysis of Elastic Plates and Shells, (CRC Press,Florida, 2006)

6. W. Kroenke, Classification of finite element stresses according to ASME section.III stress categories. ASME Winter Annual Meeting, Detroit, MI, 107 (1973)

7. J. Hechmer, G. Hollinger, 3D stress criteria (phase 2): guidelines for application, (NY: Pressure Vessel Research, 1998).

8. G. Hollinger, J. Hechmer, Three-dimensional stress criteria-summary of the PVRC project. ASME J Press Vessel Technology, 122(1), 105-109 (2000)

9. B. Gao, X. Chen, An approach to derive primary bending stress from finite element analysis for pressure vessels and applications in structural design. ASME J Press Vessel Technology, 302, 061101-1, (2010)

10. P. Godbole, P. Supak, A new method for stress categorization on planes, ASME J Press Vessel Technol, 132, 061206-1 (2010)

11. H. Li, X. Huang, P. Yang, et al, INT J PRES VES PIP, 152,38, (2017) 